\title{
Prevalence AND INTENSITY OF ANGIOStRONGyLUS CANTONENSIS IN FRESHWATER SNAILS IN RELATION TO SOME ECOLOGICAL AND BIOLOGICAL FACTORS
}

\author{
IBRAHIM M.M.*
}

\section{Summary :}

The purpose of the study was to record different intermediate hosts of $A$. cantonensis and to determine the infection prevalence and intensity of this parasite in freshwater snails in relation to some ecological and biological factors. The study was conducted at AlSalam irrigation Canal and Al-Abtal village (north Sinai) for one year, from March 2004 to February 2005. Thirteen species of freshwater snails of nine families were examined for

A. cantonensis infection. Six species were found infected with A. cantonensis larvae. These species were L. carinatus,

C. bulimoides, C. cyclostomoides, B. alexandrina, L. natalensis and $M$. tuberculta. The infection prevalence of $A$. cantonensis in the examined snails ranged from 0.63 to $2.24 \%$. L. carinatus snail had the highest prevalence, mean abundance and mean intensity of $A$. cantonensis infection. Positive correlations were found between both prevalence and mean abundance of A. cantonensis and host size in L. carinatus and M. tuberculata. Negative correlations were detected between salinity and prevalence, mean abundance and mean intensity of larvae of A. cantonensis. The results demonstrated seasonal and spatial variation in the prevalence, mean abundance and mean intensity of infection among examined snails. In this study, A. cantonensis larvae were found in a wide range of freshwater snails and M. tuberculata snail was recorded as a new intermediate host for the first time. In conclusion, further investigations in other areas and controlled laboratory experiments of infection approaches are required to evaluate the possible threat of this parasite on humans.

KEY WORDS : Angiostrongylus cantonensis, freshwater snail, intermediate host, size, salinity, prevalence.
Résumé : PRÉVALENCE ET INTENSITÉ D'ANGIOSTRONGYLUS CANTONENSIS CHEZ DES MOlLusques D'EAu DOUCE CORRÉlÉES À DES FACTeUrS ÉCOLOGIQUES ET BIOLOGIQUES

Étude de la prévalence et de l'intensité de l'infection par A. cantonensis chez différents mollusques d'eau douce, hôtes intermédiaires, corrélativement à des facteurs écologiques et biologiques. L'étude a été menée au niveau du canal d'irrigation d'Al-Salam et du village d'Al-Abtal au nord du Sinaï, de mars 2004 à février 2005. L'infection par A. cantonensis a été recherchée chez 13 espèces de mollusques d'eau douce appartenant à neuf familles. Des larves d'A. cantonensis ont été retrouvées chez six espèces : L. carinatus, C. bulimoides, C. cyclostomoides, B. alexandrina, L. natalensis et $M$. tuberculta. La prévalence de l'infection par A. cantonensis chez les mollusques s'échelonnais de 0,63 à 2,24\%. L. carinatus présentait les prévalence, abondance et intensité moyennes d'infection par A. cantonensis les plus élevées. Des corrélations positives ont été observées entre à la fois la prévalence et l'abondance moyenne d'A. cantonensis et la taille de l'hôte chez $L$. carinatus et $M$. tuberculata. Des corrélations négatives ont été détectées entre la salinité et la prévalence et les abondances et intensités moyennes des larves d'A. cantonensis. Ces résultats démontrent des variations saisonnières et spatiales des prévalences, abondances et intensités moyennes d'infection chez les mollusques examinés. Des larves d'A. cantonensis ont été retrouvées chez divers mollusques d'eau d'ouce et $M$. tuberculata a été pour la première fois recensé en tant que nouvel hôte intermédiaire. Des investigations dans d'autres sites et des expériences en laboratoires seront nécessaires afin de mieux évaluer les risques d'infection humaine par A. cantonensis.

MOTS CLÉS : Angiostrongylus cantonensis, mollusque d'eau douce, hôte intermédiaire, taille, salinité, prévalence.

Caledonia, Thailand, Vanuatu, the Loyalty Islands, Cuba, and even in Louisiana (Alicata, 1969; Chao et al., 1987).

A. cantonensis is the most common parasitic cause of eosinophilic meningitis (EM). By convention, EM is defined by the presence of greater than or equal to 10 eosinophils per microliter of CSF or greater than or equal to $10 \%$ of the total CSF leukocyte count (Kuberski, 1981). The adult worms reside in the pulmonary vasculature of the rat, where they lay eggs that hatch into larvae. These first stage larvae are in turn swallowed and passed out in the rat feces. Intermediate hosts then feed on the contaminated rat feces.

Mollusks such as certain snails and slugs serve as intermediate hosts wherein the larvae undergo two
* Zoology department, Faculty of Science, Suez Canal University, Ismailia, Egypt.

Tel.: 00966 (0) 557605137 - Fax: 00966 (0) 77240308.

E-mail: m_mossa77@hotmail.com 
molts and develop into third-stage infective forms. Occasionally, freshwater prawns, crabs, frogs, and planaria may serve as paratenic, or carrier hosts. When noninfected rats ingest intermediate hosts, the larvae penetrate the intestine and are disseminated by the circulatory system where they reach the central nervous system and undergo two additional molts to become young adult worms and subsequently reach the pulmonary artery to complete their life cycle. Humans become infected by eating infected intermediate or paratenic hosts, or by eating food such as leafy green vegetables contaminated by these hosts (Rosen et al., 1967; Ash, 1976). Humans are "dead end" hosts in that the neurotropic larvae migrate to the central nervous system, but are unable to complete their life cycle and subsequently die. The death of these larvae is thought to result in diffuse meningeal inflammation characterized by an eosinophilic infiltration (Slom \& Johnson, 2003).

Most cases of $A$. cantonensis meningitis have been reported in Southeast Asia and the Pacific Basin, (Uchikawa et al., 1984; Kliks \& Palumbo, 1992) but sporadic cases have been reported in many other regions (Heaton \& Gutteridge, 1980; Brown et al., 1996).

$P$. cantonensis was discovered for the first time in Egypt by Yousif \& Ibrahim (1978). The rat, Rattus norvegicas is the final host and harbours adult worm in pulmonary arteries and Lanistes carinatus act as intermediate host (Yousif \& Ibrahim, 1978; Ibrahim \& Yousif, 1983). In addition to rats, other species of mammals such as dogs have been found to be naturally infected (Ibrahim \& Yousif, 1983).

There is no clear data about the geographical distribution of this parasite and its most conspicuous intermediate hosts are not known in Egypt (Ibrahim \& Yousif, 1983; El-Shazly et al., 2002). This parasite is not highly specific for either its definitive (rats) or intermediate (molluscs) hosts (Beaver et al., 1984; Kliks \& Palumbo, 1992). Therefore, this work aimed to record different intermediate hosts and study the prevalence and abundance of this parasite in relation to some ecological and biological factors.

\section{MATERIALS AND METHODS}

T The study area was Al-Salam irrigation Canal (Fig. 1; sites 1-7) and Al-Abtal village, a new cultivated area in north Sinai (northern latitude $30^{\circ} 45^{\prime}$, western longitude $32^{\circ} 25^{\prime}$; sites 8 and 9). Seven sites were chosen across Al-Salam irrigation Canal and two sites in the Al-Abtal village, site 8 is the irrigation canal and site 9 is the drain canal. Temperature was measured in each site by using a laboratory glass mercuric $100^{\circ} \mathrm{C}$ thermometer. Salinity was measured in each site by using a hand refractometer (ATAGO, S/mill, Salinity 0-100 \%, Chem. Lab Scientific product Ltd). The salinity reported as part per thousand (\%o).

Monthly samples of freshwater snails were collected for one year (March 2004 to February 2005). Sampling was performed using a wire net, its aperture $33 \mathrm{~cm}$ in length and width and 8 in depth (WHO, 1965). Snails were systematically identified according to Brown et al. (1984) and Ibrahim et al. (2004). The collected snails were measured with calipers (shell length for conic shells and shell diameter for discoid shells), then examined to detect and count larvae of $P$. cantonensis according to the method adopted by Ibrahim \& Yousif (1983). To liberate the encapsulated $3^{\text {rd }}$ stage larvae (L3) of the parasite, each snail was finely minced, dropped in a digestive solution (10\% pepsin-Hcl) and kept for two hours over a magnetic stirrer at $37^{\circ} \mathrm{C}$. The

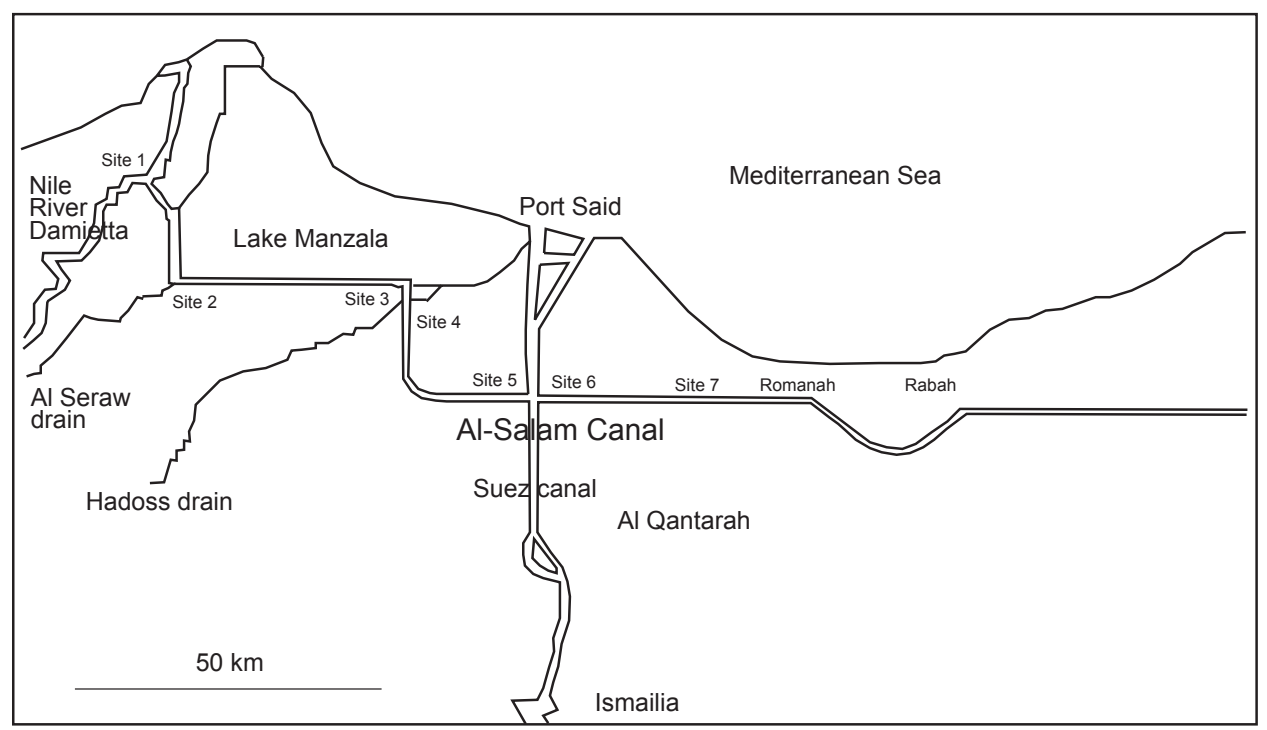

Fig. 1. - Map of study areas in Al-Salam irrigation Canal (sites $1-7)$. 
digest was left to sediment and then the larvae were counted (El-Shazly et al., 2000).

Summary of statistics were presented as mean abundance and mean intensity \pm SE of infection according to Bush et al. (1997). The prevalence was calculated according to Bush et al. (1997). Correlations between host size (shell length or shell diameter) and prevalence, mean abundance and mean intensity of infection were examined using the non-parametric Spearman's rank correlation coefficients $\left(r_{s}\right)$. The degree of aggression of $P$. cantonensis in different host species was calculated by the Index of dispersion ( $\mathrm{I}=$ the variance to mean ratio (V/M: $\mathrm{I}>1$ indicating overdispersion) and the Index of discrepancy (D) as described by Poulin (1993): a value of 0 indicates an even distribution of accounts across all hosts, and a value of one indicates all parasites aggregated in a single host. ANOVA was used to test the differences in salinity and temperature temporally and spatially. Prevalence data were analyzed using a contingency table analysis with G-test for goodness of fit. Mann-Whitney U-test and Kruskal-Wallis test for differences in parasite mean abundance and intensity among host species, seasons and sites. All the statistical tests were performed by using the software packages SPSS 12.00 (USA).

\section{RESULTS}

There was a monthly variation in water temperature in all sites. The mean values of temperature ranged from $13.45^{\circ} \mathrm{C}$ to $31.8^{\circ} \mathrm{C}$, the highest one was recorded in summer during July whereas the lowest one was recorded during winter in January. Temporal significant difference in temperature was found $(P<0.0001)$. On the other hand, there was no significant difference in temperature among sites in both Al-Salam Canal and Al-Abtal village $(P>0.05)$. Spatial variation in salinity was found among different sites of study area (Table IV). There was a significant difference in salinity among sites of Al-Salam Canal $\left(\mathrm{F}_{6,21}=98.336, P<0.0001\right)$ and between sites of Al-Abtal village $(t=-7.89, P<0.0001)$.

The community of freshwater snails in Al-Salam irrigation Canal composed of 11 species, Lanistes carinatus, Bellamya unicolor, Melanoides tuberculata, Cleopatra bulimoides, Cleopatra cyclostomoides, Theodoxus niloticus, Helisoma duryi, Biomphalaria alexandrina, Bulinus truncatus, Physa acuta and Lymnaea natalensis. The community of snails in Al-Abtal village consisted of 13 species. These species were Vavata nilotica, Gabbiella senaariensis, L. carinatus, B. unicolor,

\begin{tabular}{|c|c|c|c|c|c|c|c|}
\hline & \multicolumn{3}{|c|}{ Al-Salam irrigation Canal } & \multicolumn{3}{|c|}{ Al-Abtal village } & \multirow{2}{*}{$\begin{array}{l}\text { Total } \\
\text { prevalence } \\
(\%)\end{array}$} \\
\hline & Examined & Infected & $\begin{array}{c}\text { Prevalence } \\
(\%)\end{array}$ & Examined & Infected & $\begin{array}{c}\text { Prevalence } \\
(\%)\end{array}$ & \\
\hline \multicolumn{8}{|l|}{$\begin{array}{l}\text { A) Subclass: Streptoneura } \\
\text { (Prosobranchia) } \\
\text { F. Valvatidae }\end{array}$} \\
\hline $\begin{array}{l}\text { Vavata nilotica } \\
\text { F. Bithyniidae }\end{array}$ & 0 & 0 & 0 & 146 & 0 & 0 & 0 \\
\hline $\begin{array}{l}\text { F. Bithyniidae } \\
\text { Gabbiella senaariensis }\end{array}$ & 0 & 0 & 0 & 729 & 0 & 0 & 0 \\
\hline F. Thiaridae & & & & & & & \\
\hline $\begin{array}{l}\text { Melanoides tuberculata } \\
\text { Cleopatra bulimoides } \\
\text { Cleopatra cyclostomoides }\end{array}$ & $\begin{array}{l}2,003 \\
1,388 \\
1,294\end{array}$ & $\begin{array}{r}6 \\
5 \\
10\end{array}$ & $\begin{array}{l}0.29 \\
0.36 \\
0.77\end{array}$ & $\begin{array}{l}2,109 \\
2,200 \\
2,107\end{array}$ & $\begin{array}{l}20 \\
36 \\
35\end{array}$ & $\begin{array}{l}0.94 \\
1.63 \\
1.66\end{array}$ & $\begin{array}{l}0.63 \\
1.14 \\
1.32\end{array}$ \\
\hline F. Neritidae & & & & & & & \\
\hline $\begin{array}{l}\text { Theodoxus niloticus } \\
\text { F. Viviparidae }\end{array}$ & 838 & 0 & 0 & 763 & 0 & 0 & 0 \\
\hline $\begin{array}{l}\text { Bellamya unicolor } \\
\text { F. Ampullaridae }\end{array}$ & 1,185 & 0 & 0 & 1,010 & 0 & 0 & 0 \\
\hline Lanistes carinatus & 1,167 & 14 & 1.19 & 1,323 & 42 & 3.17 & 2.24 \\
\hline $\begin{array}{l}\text { B) Subclass: Euthyneura } \\
\text { (Pulmonata) } \\
\text { F. Planorbidae }\end{array}$ & & & & & & & \\
\hline Biomphalaria alexandrina & 80 & 0 & 0 & 214 & 3 & 1.4 & 1.02 \\
\hline Bulinus truncatus & 458 & 0 & 0 & 329 & 0 & 0 & 0 \\
\hline $\begin{array}{l}\text { Helisoma duryi } \\
\text { F. Lvmnaeidae }\end{array}$ & 232 & 0 & 0 & 176 & 0 & 0 & 0 \\
\hline $\begin{array}{l}\text { Lymnaea natalensis } \\
\text { F. Physidae }\end{array}$ & 36 & 0 & 0 & 182 & 2 & 1.09 & 0.92 \\
\hline Physa acuta & 710 & 0 & 0 & 313 & 0 & 0 & 0 \\
\hline Total & 9,391 & 35 & 0.37 & 11,601 & 138 & 1.19 & 0.82 \\
\hline
\end{tabular}

Table I. - Numbers and types of examined snails for prevalence (\%) of P. cantonensis larvae in the study area (Al-Salam Canal and AlAbtal village, new cultivated area in north Sinai). 

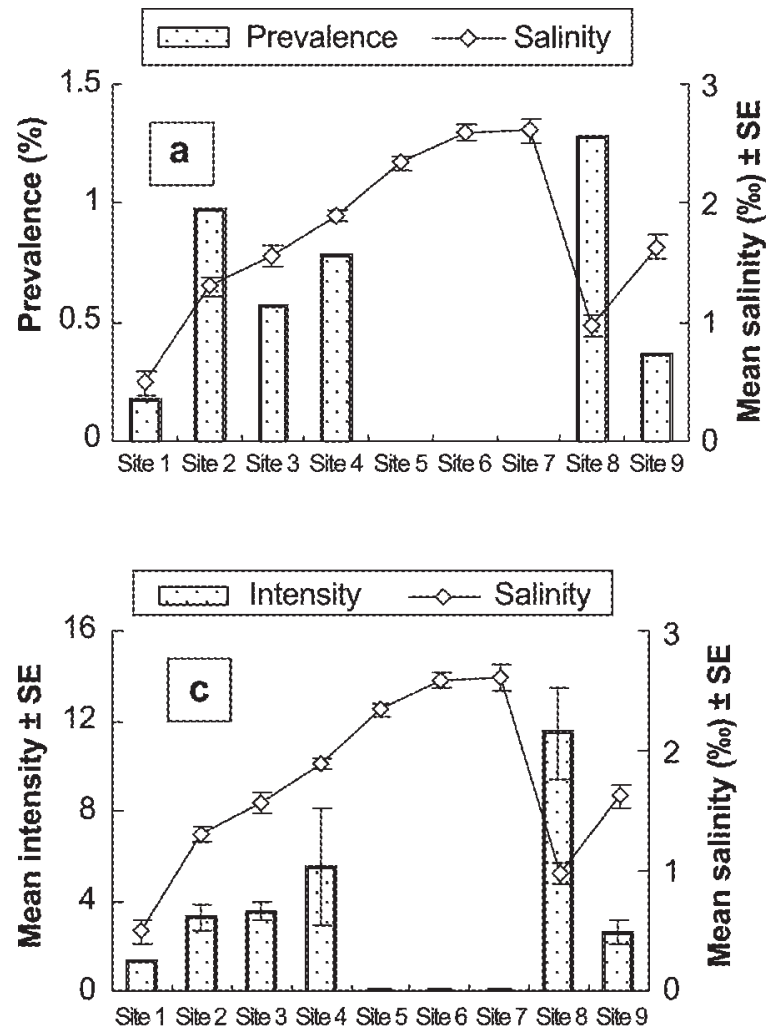

M. tuberculata, C. bulimoides, C. cyclostomoides, T. niloticus, $H$. duryi, B. alexandrina, B. truncatus, P. acuta and $L$. natalensis (Table I). Six species were found infected with $A$. cantonensis larvae in the study area. These species were L. carinatus, C. bulimoides, C. cyclostomoides, B. alexandrina, L. natalensis and M. tuberculata. The total number of collected snails was 9,391 and 11,601 for Al-Salam Canal and Al-Abtal village respectively. The total prevalence of $A$. cantonensis in AlSalam Canal and Al-Abtal village were $0.37 \%$ and $1.19 \%$ respectively (Table I).

The prevalence, mean abundance and mean intensity of infection decreased as the salinity increased (Fig. 2). Negative correlations were found between salinity and prevalence, mean abundance and intensity of infection and $\left(r_{\mathrm{s}}=-0.3, P<0.0001 ; r_{\mathrm{s}}=-0.28, P<0.0001\right.$ and $r_{\mathrm{s}}=-0.17, P=0.03$ for prevalence, abundance and intensity respectively). Removing the data of site 8 , no correlations were found between salinity and prevalence, mean abundance or mean intensity. However, no infected snails were recorded in sites 5, 6 and 7 where the salinity showed the higher values.

The results demonstrated variation in total prevalence of $A$. cantonensis larvae among different host species. The infection prevalences were $2.24 \%, 1.32 \%, 1.14 \%$, $1.02 \%, 0.92 \%$ and $0.63 \%$ in L. carinatus, C. cyclostomoides, C. bulimoides, B. alexandrina, L. natalensis and $M$. tuberculata respectively (Table I). Prevalence of $A$. cantonensis infection was not independent of spe-

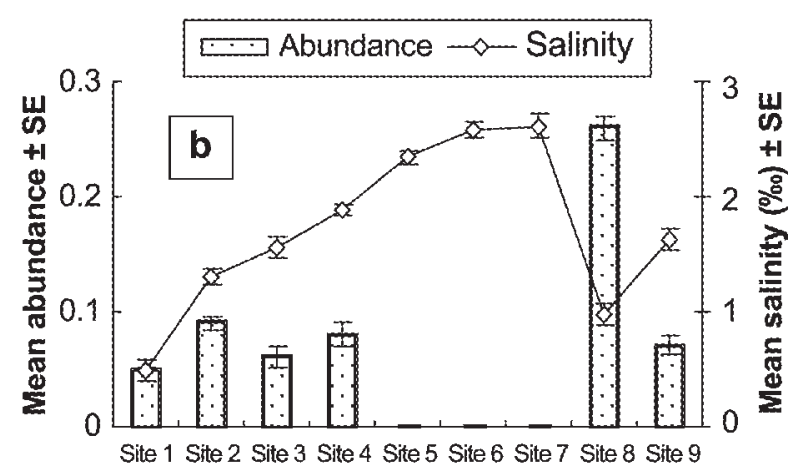

Fig. 2. - Mean spatial variation of salinity $(\% 0)$ and the relationship between salinity and prevalence (a), mean abundance (b) and mean intensity (c) in the study area. cies $\left(\chi^{2}=58.18, P<0.0001\right)$. The prevalence was lower than expected in M. tuberculata snails and was higher than expected in L. carinatus, C. cyclostomoides, C. bulimoides, B. alexandrina and L. natalensis. L. carinatus snail had the highest infection prevalence $(2.24 \%)$ (Table I). M. tuberculata was recorded for the first time as intermediate host for $A$. cantonensis and has the lowest infection prevalence $(0.63 \%)$. There were variations in mean abundance and intensity among host species (Tables II-IV). The mean abundance and mean intensity differed significantly among host species $\left(\chi^{2}=\right.$ 51.907, $P<0.0001$ and $\chi^{2}=40.248, P<0.0001$ for mean abundance and mean intensity respectively). The highest intensity of infection was recorded in $L$. carinatus $(97$ larvae per snail). The intensity of infection in L. carinatus ranged from 1 to 97 . On the other hand, M. tuberculata had the lowest abundance (0-5 larvae/ snail) and intensity (1-5 larvae/snail) of infection (Tables II-IV). The nematode larvae were aggregated in all mollusc species (all I $>1$ ). The results showed that $L$. carinatus had the highest degree of aggregation of $A$. cantonensis when compared with other infected snails (Table V).

The prevalence of infection increased with increasing snail size of L. carinatus and M. tuberculata (Fig. 3). Positive correlations were found between infection prevalence of larvae of $A$. cantonensis and snail size in L. carinatus $\left(r_{s}=0.2, P<0.02\right)$ and $M$. tuberculata (Fig. 3; $r_{s}=0.16, P<0.0001$ ). There were positive correlations between mean abundance of larvae of $A$. can- 


\begin{tabular}{|c|c|c|c|c|c|}
\hline & & Spring & Summer & Autumn & Winter \\
\hline \multirow[t]{3}{*}{ L. carinatus } & $\begin{array}{c}\text { Abundance (Mean } \pm \text { SE) } \\
\text { (Range) }\end{array}$ & $\begin{array}{c}0.03 \pm .02 \\
(0-4)\end{array}$ & $\begin{array}{l}0.09 \pm 0.04 \\
\quad(0-17)\end{array}$ & $\begin{array}{l}0.12 \pm 0.08 \\
\quad(0-30)\end{array}$ & 0 \\
\hline & $\begin{array}{c}\text { Intensity (Mean } \pm \text { SE) } \\
\text { (Range) }\end{array}$ & $\begin{array}{l}3 \pm 1 \\
(2-4)\end{array}$ & $\begin{array}{l}5.83 \pm 2.52 \\
\quad(1-17)\end{array}$ & $\begin{array}{l}19.5 \pm 10.5 \\
\quad(9-30)\end{array}$ & 0 \\
\hline & Prevalence (\%) & 1.1 & 1.29 & 0.51 & 0 \\
\hline \multirow[t]{3}{*}{ C. cyclostomoides } & $\begin{array}{c}\text { Abundance (Mean } \pm \text { SE) } \\
\text { (Range) }\end{array}$ & $\begin{array}{l}0.03 \pm 0.01 \\
(0-4)\end{array}$ & $\begin{array}{l}0.02 \pm 0.01 \\
\quad(0-3)\end{array}$ & $\begin{array}{l}0.01 \pm 0.01 \\
(0-5)\end{array}$ & 0 \\
\hline & $\begin{array}{c}\text { Intensity (Mean } \pm \text { SE) } \\
\text { (Range) }\end{array}$ & $\begin{array}{l}2.20 \pm 0.58 \\
\quad(1-4)\end{array}$ & $\begin{array}{l}1.75 \pm 0.48 \\
\quad(1-3)\end{array}$ & $\begin{array}{c}5 \\
(5-5)\end{array}$ & 0 \\
\hline & Prevalence (\%) & 1.18 & 1.08 & 0.29 & 0 \\
\hline \multirow[t]{3}{*}{ C. bulimoides } & $\begin{array}{c}\text { Abundance }(\text { Mean } \pm S E) \\
\text { (range) }\end{array}$ & $\begin{array}{l}0.01 \pm 0.01 \\
(0-2)\end{array}$ & $\begin{array}{l}0.01 \pm 0.01 \\
(0-3)\end{array}$ & $\begin{array}{c}0.004 \pm 0.001 \\
(0-2)\end{array}$ & 0 \\
\hline & $\begin{array}{c}\text { Intensity (Mean } \pm \text { SE) } \\
\text { (Range) }\end{array}$ & $\begin{array}{c}2 \\
(2-2)\end{array}$ & $\begin{array}{c}2 \pm 0.58 \\
(1-3)\end{array}$ & $\begin{array}{c}2 \\
(2-2)\end{array}$ & 0 \\
\hline & Prevalence $(\%)$ & 0.25 & 0.51 & 0.19 & 0 \\
\hline \multirow[t]{3}{*}{ M. tuberculata } & $\begin{array}{c}\text { Abundance (Mean } \pm \text { SE) } \\
\text { (Range) }\end{array}$ & $\begin{array}{c}0.003 \pm 0.001 \\
(0-2)\end{array}$ & $\begin{array}{c}0.002 \pm 0.001 \\
(0-3)\end{array}$ & $\begin{array}{c}0.001 \pm 0.0005 \\
(0-2)\end{array}$ & 0 \\
\hline & $\begin{array}{c}\text { Intensity (Mean } \pm \text { SE) } \\
\text { (Range) }\end{array}$ & $\begin{array}{c}1.33 \pm 0.33 \\
(1-2)\end{array}$ & $\begin{array}{l}2 \pm 1 \\
(1-3)\end{array}$ & $\begin{array}{c}2 \\
(2-2)\end{array}$ & 0 \\
\hline & Prevalence (\%) & 0.24 & 0.12 & 0.07 & 0 \\
\hline
\end{tabular}

*There were no infected B. alexandrina and L. natalensis snails recorded in Al-Salam Canal.

Table II. - Seasonal prevalence, mean abundance and intensity of $P$. cantonensis larvae infection among different freshwater snails in AlSalam Canal.

\begin{tabular}{|c|c|c|c|c|c|}
\hline & & Spring & Summer & Autumn & Winter \\
\hline \multirow[t]{3}{*}{ L. carinatus } & $\begin{array}{c}\text { Abundance (Mean } \pm \text { SE) } \\
\text { (Range) }\end{array}$ & $\begin{array}{c}0.88 \pm 0.34 \\
(0-76)\end{array}$ & $\begin{array}{l}1.25 \pm 0.38 \\
(0-97)\end{array}$ & $\begin{array}{c}0.56 \pm 0.30 \\
(0-93)\end{array}$ & $\begin{array}{l}0.02 \pm 0.02 \\
\quad(0-3)\end{array}$ \\
\hline & $\begin{array}{c}\text { Intensity (Mean } \pm \text { SE) } \\
\text { (Range) }\end{array}$ & $\begin{array}{l}32.18 \pm 8.88 \\
\quad(3-76)\end{array}$ & $\begin{array}{c}37.62 \pm 9.38 \\
(1-97)\end{array}$ & $\begin{array}{l}33.6 \pm 18.33 \\
(2-93)\end{array}$ & $\begin{array}{l}2 \pm 1 \\
(1-3)\end{array}$ \\
\hline & Prevalence (\%) & 2.66 & 2.88 & 1.37 & 1.12 \\
\hline \multirow[t]{3}{*}{ C. cyclostomoides } & $\begin{array}{c}\text { Abundance (Mean } \pm \text { SE) } \\
\text { (Range) }\end{array}$ & $\begin{array}{l}0.03 \pm 0.01 \\
(0-7)\end{array}$ & $\begin{array}{l}0.05 \pm 0.01 \\
\quad(0-7)\end{array}$ & $\begin{array}{l}0.01 \pm 0.01 \\
\quad(0-7)\end{array}$ & 0 \\
\hline & $\begin{array}{c}\text { Intensity (Mean } \pm \text { SE) } \\
\text { (Range) }\end{array}$ & $\begin{array}{c}3.11 \pm 0.77 \\
(1-7)\end{array}$ & $\begin{array}{l}3.50 \pm 0.40 \\
\quad(1-7)\end{array}$ & $\begin{array}{c}7 \\
(7-7)\end{array}$ & 0 \\
\hline & Prevalence (\%) & 0.81 & 1.46 & 0.13 & 0 \\
\hline \multirow[t]{3}{*}{ C. bulimoides } & $\begin{array}{c}\text { Abundance (Mean } \pm \text { SE) } \\
\text { (Range) }\end{array}$ & $\begin{array}{l}0.03 \pm 0.01 \\
(0-6)\end{array}$ & $\begin{array}{l}0.05 \pm 0.01 \\
\quad(0-7)\end{array}$ & $\begin{array}{l}0.01 \pm 0.01 \\
\quad(1-5)\end{array}$ & $\begin{array}{c}0.001 \pm 0.001 \\
(0-1)\end{array}$ \\
\hline & $\begin{array}{c}\text { Intensity (Mean } \pm \text { SE) } \\
\text { (Range) }\end{array}$ & $\begin{array}{l}3.10 \pm 0.53 \\
\quad(1-6)\end{array}$ & $\begin{array}{c}3.36 \pm 0.37 \\
(1-7)\end{array}$ & $\begin{array}{l}3.33 \pm 1.20 \\
\quad(1-5)\end{array}$ & $\begin{array}{c}1 \\
(1-1)\end{array}$ \\
\hline & Prevalence (\%) & 1.04 & 1.45 & 0.29 & 0.48 \\
\hline \multirow[t]{3}{*}{ M. tuberculata } & $\begin{array}{c}\text { Abundance (Mean } \pm \text { SE) } \\
\text { (Range) }\end{array}$ & $\begin{array}{c}0.01 \pm 0.001 \\
(0-3)\end{array}$ & $\begin{array}{c}0.01 \pm 0.001 \\
(0-5)\end{array}$ & $\begin{array}{l}0.02 \pm 0.01 \\
(0-5)\end{array}$ & 0 \\
\hline & $\begin{array}{c}\text { Intensity (Mean } \pm \text { SE) } \\
\text { (Range) }\end{array}$ & $\begin{array}{c}1.50 \pm 0.34 \\
(1-3)\end{array}$ & $\begin{array}{c}2.14 \pm 0.55 \\
(1-5)\end{array}$ & $\begin{array}{c}3 \pm 0.65 \\
(1-5)\end{array}$ & 0 \\
\hline & Prevalence $(\%)$ & 0.41 & 0.51 & 0.57 & 0 \\
\hline \multirow[t]{3}{*}{ L. natalensis } & $\begin{array}{c}\text { Abundance (Mean } \pm \text { SE) } \\
\text { (Range) }\end{array}$ & 0 & $\begin{array}{l}0.03 \pm 0.03 \\
(0-4)\end{array}$ & 0 & 0 \\
\hline & $\begin{array}{c}\text { Intensity (Mean } \pm \text { SE) } \\
\text { (Range) }\end{array}$ & 0 & $\begin{array}{c}2 \pm 1 \\
(1-3)\end{array}$ & 0 & 0 \\
\hline & Prevalence (\%) & 0 & 1.65 & 0 & 0 \\
\hline \multirow[t]{3}{*}{ B. alexandrina } & $\begin{array}{c}\text { Abundance (Mean } \pm \text { SE) } \\
\text { (Range) }\end{array}$ & 0 & $\begin{array}{l}0.03 \pm 0.02 \\
(0-2)\end{array}$ & $\begin{array}{l}0.03 \pm 0.03 \\
(0-3)\end{array}$ & 0 \\
\hline & $\begin{array}{c}\text { Intensity (Mean } \pm \text { SE) } \\
\text { (Range) }\end{array}$ & 0 & $\begin{array}{l}1.5 \pm 0.5 \\
(1-2)\end{array}$ & $\begin{array}{c}3 \\
(3-3)\end{array}$ & 0 \\
\hline & Prevalence (\%) & 0 & 2.15 & 1.04 & 0 \\
\hline
\end{tabular}

Table III. - Seasonal prevalence, mean abundance and intensity of $P$. cantonensis infection among different freshwater snails in Al-Abtal village (a new cultivated area in north Sinai). 


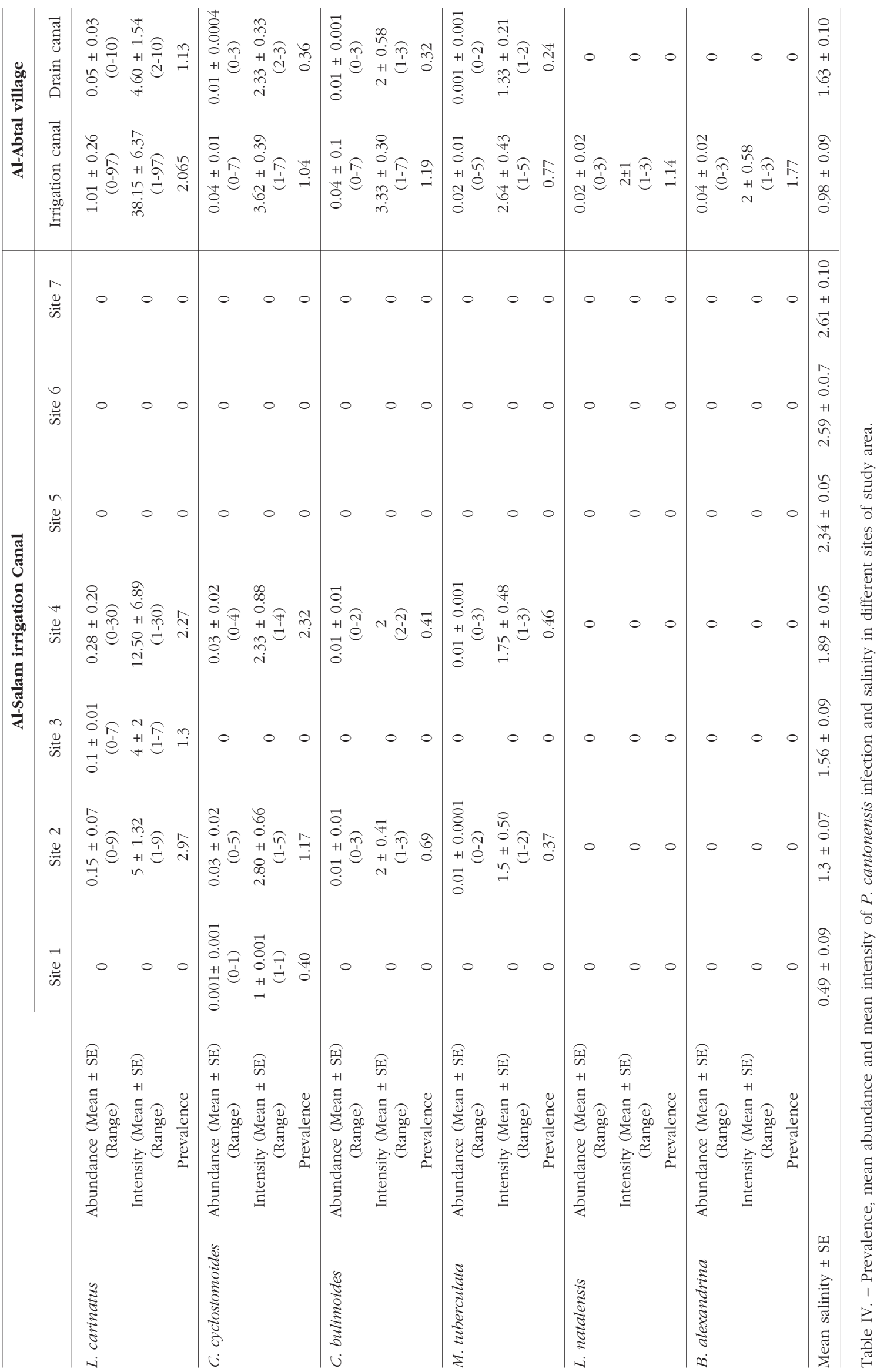



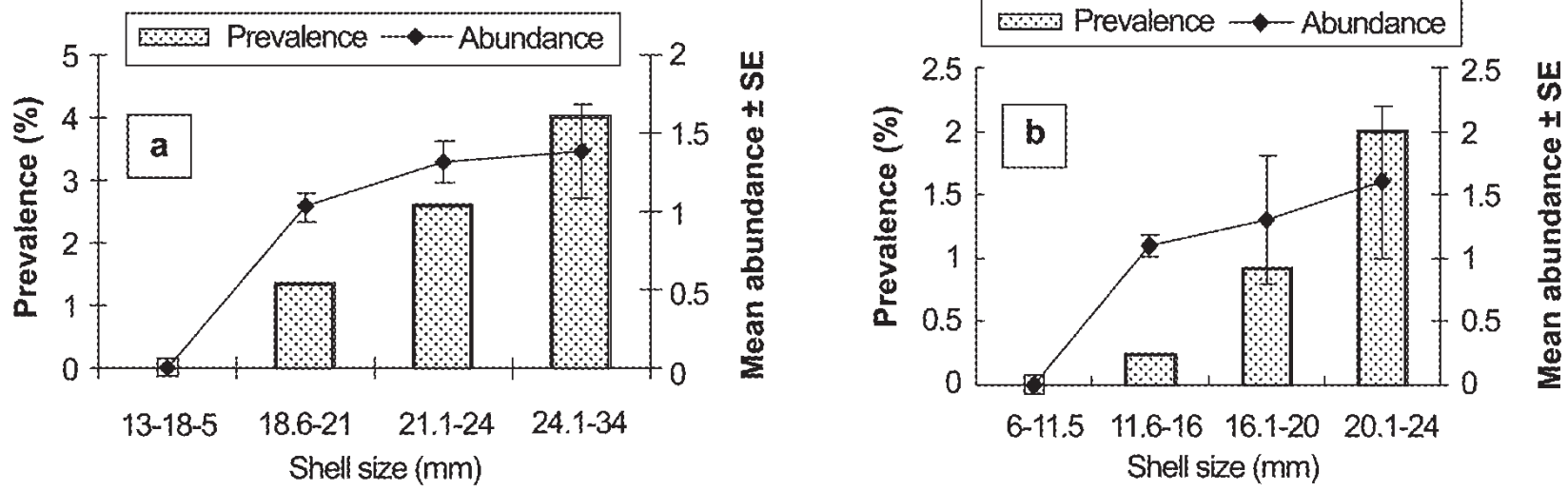

Fig. 3. - Infection prevalence and mean abundance ( \pm SE) of P. cantonensis in relation to shell size (mm) in L. carinatus (a) and M. tuberculata (b).

\begin{tabular}{lrc}
\hline & I & D \\
\hline L. carinatus & 56.49 & 0.986 \\
C. cyclostomoides & 4.43 & 0.991 \\
C. bulimoides & 3.96 & 0.993 \\
M. tuberculata & 2.95 & 0.996 \\
L. natalensis & 2.49 & 0.986 \\
B. alexandrina & 2.32 & 0.986 \\
\hline
\end{tabular}

Table V. - Indices of aggregation of P. cantonensis in infected freshwater snails.

tonensis and snail size of both $L$. carinatus $\left(r_{s}=0.02\right.$, $P=0.001)$ and $M$. tuberculata $\left(r_{s}=0.15, P<0.0001\right)$. The mean intensity of infection was positively correlated with snail size in only L. carinatus snails $\left(r_{s}=\right.$ $0.773, P<0.0001)$ but this result was not found in other snail species. On the other hand, other infected snail did not show any correlations between host size and infection prevalence, mean abundance or mean intensity.

The results demonstrated seasonal variations in infection prevalence, abundance and intensity of $A$. cantonensis (Tables II-III). Prevalence of $A$. cantonensis infection was not independent of season $\left(\chi^{2}=25.03, P<\right.$ 0.0001). The prevalence was lower than expected during the winter and autumn and was higher than expected during summer and spring. There were significant differences in infection abundance and intensity among seasons $\left(\chi^{2}=24.349, P<0.0001\right.$ and $\chi^{2}=8.35$, $P<0.039$ for prevalence, abundance and intensity respectively). Summer showed the highest combined prevalence $(1.12 \%)$.

Spatial variations in the infection prevalence, mean abundance and mean intensity were found. Prevalence of $A$. cantonensis infection was not independent of sites $\left(\chi^{2}=83.236, P<0.0001\right)$. The prevalence was lower than expected at sites 1, 3, 5, 6 and 7 and was higher than expected in sites 2, 4, 8 and 9. There were significant differences in mean abundance and mean intensity among sites $\left(\chi^{2}=80.289, P<0.0001\right.$ and $\chi^{2}=$ $12.913, P<0.012$ for abundance and intensity respectively). Overall prevalence, mean abundance differed significantly between Al-Salam Canal and Al-Abtal village locations (Table I, $\chi^{2}=80.289, P<0.0001$ and $U=$ 5.8, $P<0.0001$ for prevalence and mean abundance respectively). The prevalence of infection was higher in Al-Abtal village (1.19\%) than that in Al-Salam Canal $(0.37 \%)$ (Table I). No infected B. alexandrina and L. natalensis snails was found in Al-Salam Canal. In Al-Abtal village, the prevalence, mean abundance and intensity of infection in irrigation canal were high when compared with drainage canal at Al-Abtal village (Table IV). When comparing the infection prevalence in different sites at Al-Salam Canal, it was found that sites after agriculture drainage water from El-Serw (site 2) and Hadoos drains (site 4) have more infected snails than other sites at Al-Salam Canal (Table IV). The prevalence and mean intensity of infection of $A$. cantonensis in irrigation canal at Al-Abtal village was higher when compared with that in drainage canal (Table IV).

\section{DISCUSSION}

T The purpose of the study was to record different intermediate hosts of $A$. cantonensis and to determine the prevalence and intensity of this parasite in relation to some ecological and biological factors. In this study, the infection prevalence of A. cantonensis in freshwater snails decreased as salinity increased. Negative correlations were found between salinity and infection prevalence, mean abundance and mean intensity. This finding may be due to the $1^{\text {st }}$ stage larvae (L1) have no tolerance to increasing salinity therefore; they are not able to infect snails and develop into $3^{\text {rd }}$ stage larvae (L3). The infection rate of Schistosoma mansoni in Biomphalaria arabica decreased as the salinity increased up to $4,500 \mathrm{mg} / \mathrm{l}$, 
above which no infection occurred (Lwambo et al., 1987). Donnelly et al. (1983) demonstrated that the fecundity and survival of $B$. africanus was adversely affected with salinities of $1 \%$ with the most significant reductions occurring between $3.5 \%$ and $4.5 \%$. Southgate (1997) and Rollinson et al. (2001) correlated the severe outbreak of $S$. mansoni and $S$. haematobium in the Senegal River to the reduction in salinity. It has been assumed that as salinity increases individuals of a species will experience no effect until a threshold is reached (Hart et al., 1991; Kefford et al., 2004). Rises in salinity above this threshold will produce reductions in biological performance, such as growth and reproduction, which are referred to as sub-lethal effects. If salinity increases further, greater levels of the sub-lethal effect will occur, until death results. With a threshold response, changes in salinity below this threshold will have no direct effect on freshwater animals. The results demonstrated that the prevalence of infection in irrigation canals was high if compared with drainage canal at Al-Abtal village. Also no infected snails were found in site 5, 6 and 7. These findings may due to the increasing salinity at these sites and the larvae of A. cantonensis may have no resistance and not being able to tolerate salinity therefore, its presence was restricted to sites with low water salinity.

The present study showed that the higher prevalence of $A$. cantonensis in L. carinatus relative to other snail species may reflect a true difference in host specificity. Alternatively, it is possible that some ecological factors might increase the chances that L. carinatus will become colonized. Thus, these snails exhibit ecological differences that might affect their relative vulnerability to different parasites. Such possibilities warrant further study. This finding is in consistency with El-Shazly et al. (2002) and Abo-Madyan et al. (2005). Yousif et al. (1989) reported that the prevalence of infection in L. carinatus ranged from 2.4 to 18.9. Pomacea australis, Biomphalaria glabrata and Marisa cornuaristis were found to be intermediate hosts for $P$. cantonensis as they were experimentally infected with the larvae (Leon-Dancel, 1970; Yousif \& Lämmler, 1975).

L. carinatus snail had the highest mean abundance, mean intensity and aggregation index (I) of $A$. cantonensis when compared with other host snails. The present finding may reflect a difference in host size. L. carinatus has higher mean host size compared with other examined hosts. Larger hosts simply provide more space and resources, thus supporting larger parasite populations. Yousif et al. (1989) reported that the intensity of infection in L. carinatus ranged from 21 and 72.9 larvae per infected snails. The results showed that the intensity of infection in L. carinatus ranged from 1 to 97. Furthermore this large numbers of larvae in $L$. carinatus, this due to the virulence of infection may be lower in new host-parasite association (Rubio-
Godoy \& Tinsley 2004). L. carinatus is the first intermediate host recorded for this parasite in Egypt by Yousif \& Ibrahim (1978) but other freshwater snails recorded later as intermediate hosts for $A$. cantonensis except Melanoides tuberculata by El-Shazly et al. (2002) and Abo-Madyan et al. (2005). In this study, Melanoides tuberculata snail recorded for the first time as intermediate hosts for $A$. cantonensis.

In the field populations of L. carinatus and M. tuberculata, both prevalence and mean abundance of infection increased as snail size increased. Positive correlations were found between snail size and both prevalence and mean abundance in L. carinatus and M. tuberculata. This age variation can be translated into differential exposure to and duration of infection among snails of differing sizes because larger-older snails may have been exposed to more $1^{\text {st }}$ stage larvae (L1). Snail itself (regardless of age) might in fact affect larvae development if, for example, a relatively large snail provides space, greater energetic resources, or both, for production of larvae. Older snails have accrued multiple infections. For both mammalian and avian schistosomes, the prevalence and intensity of infection tends to be highest among the largest snails (Loker, 1983; Woolhouse, 1989; Niemann \& Lewis, 1990; Graham, 2003). Large snails are older, on average than small snails, within a given population (Minchella et al., 1985).

Seasonal patterns of the prevalence and intensity of A. cantonensis infecting snails were examined; the present data indicate peaks in combined prevalence and intensity during summer and spring. This may attributed to the availability of L1 in summer and spring as a source of infection which released with rat faeces. Furthermore, during spring and summer, the gastropods are active but during winter, most of them not available or hibernating (Kutz et al., 2002). The present patterns are in consistence with the finding of El-Shazly et al. (2002). In contrary, Rosen et al. (1967) observed a marked seasonal occurrence of angiostrongyliasis in New Caledonia and noted, as had Alicata (1969) previously, a correlation between cases of human disease and the peak vegetable growing season during the cooler months of the year. Ash (1976) found that most cases of eosinophilic meningitis in New Caledonia occurred during and just after the cool season, in direct association, not with small snails of a size easily overlooked on raw vegetation, but with the influx of infected planarians in local produce gardens, and their subsequent accidental ingestion on lettuce or other raw vegetable products.

The present data demonstrated a significant difference in total prevalence among the study sites. Irrigation canal at Al-Abtal village has higher prevalence and intensity compared with other sites in both Al-Salam Canal and Al-Abtal village. These data may be interpreted as the sites differed in many habitat characte- 
ristics (e.g., depth, substrate, salinity, and associated biota). Infection prevalence in Al-Abtal village was higher $(0.92 \%)$ when compared with that in Al-Salam Canal $(0.36 \%)$. This may be due to the fact that AlAbtal village has more definitive host (Rattus norvegicas) for A. cantonensis, therefore there was a source of infection for snails in the village.

In conclusion, further investigations in other areas are needed and controlled laboratory experiments of infection approaches are required to evaluate the possible threat of this parasite on humans.

\section{REFERENCES}

Abo-Madyan A.A., Morsy T.A., Motawea S.M., El Garhy M.F. \& Massoud A.M. Spot light survey on fresh-water snails of medical importance in Al Fayoum Governorate, Egypt. Journal of Egyptian Society of Parasitology, 2005, 35 (1), 49-58.

Alicata J. Present status of Angiostrongylus cantonensis infection in man and animals in the tropics. Journal of Tropical Medicine and Hygiene, 1969, 72, 53-63.

AsH L.R. Observations on the role of mollusks and planarians in the transmission of Angiostrongylus cantonensis infection to man in New Caledonia. Review of Biology of Tropics, 1976, 24, 163-174.

Beaver P.C., Jung R.C. \& Cupp E.W. The Strongylida: hookworms and other bursate nematodes. In: Clinical Parasitology, $9^{\text {th }}$ Edition. Philadelphia: Lea \& Febiger, 1984, 269-301.

Brown F.M., Mohareb E.W., Yousif F., Sultan N. \& Girgis N.I. Angiostrongylus eosinophilic meningitis in Egypt. Lancet, 1996, 348, 964-965.

ChaO D., Lin C.C. \& Chen Y.A. Studies on growth and distribution of Angiostrongylus cantonensis larvae in Ampullarium canaliculatus. Southeast Asian Journal of Tropical Medicine and Public Health, 1987, 18 (2), 248-252.

Donnelly F.A., Appleton C.C. \& SchutTe C.H. The influence of salinity on certain aspects of the biology of Bulinus (Physopsis) africanus. International Journal of Parasitology, 1983, 13 (6), 539-545.

El-Shazly A.M., El-Hamshary E.M., El-Shewy K.M., RifaAT M.M. \& EL-SHARKAWY I.M. Incidence of Parastrongylus cantonensis larvae in different freshwater snails in Dakahlia Governorate. Journal of Egyptian Society of Parasitolology, 2002, 32 (2), 579-588.

GraHam A.L. Effects of snail size and age on the prevalence and intensity of avian schistosome infection: relating laboratory to field studies. Journal of Parasitolology, 2003, 89 (3), 458-463.

Hart B., Bailey P., Edwards P., Hortle K., James K., McMahon A., Meredith C. \& Swadling K. A review of salt sensitivity of Australian freshwater biota. Hydrobiologia, 1991, 210, 105-144

Heaton D.C. \& GutTeridge B.H. Angiostrongyliasis in Australia. Australia and New Zealand Journal of Medicine, 1980, 10, 255-256.
IBRAHIM A. \& YousIF F. The freshwater Ampullariid snail Lanistes carinatus as a natural intermediate host of Angiostrongylus cantonensis in Egypt. Journal of Egyptian Society of Parasitology, 1983, 13 (1), 117-124.

Ibrahim M.M., Shalaby I.M. \& Ghobashy A. Distribution of freshwater snails in Ismailia governorate. Proceedings of International Conference of Biological Science, 2004, 3 (1), 142157.

Kefford B.J., Papas P.J., Metzeling L. \& Nugegoda D. Do laboratory salinity tolerances of freshwater animals correspond with their field salinity? Environmental Pollution, 2004, 129, 355-362.

Kliks M.M. \& Palumbo N.E. Eosinophilic meningitis beyond the Pacific Basin: the global dispersal of a peridomestic zoonosis caused by Angiostrongylus cantonensis, the nematode lungworm of rats. Society of Science and Medicine, 1992, 34, 199-212.

KUBERSKI T. EOsinophils in cerebrospinal fluid: criteria for eosinophilic meningitis. Hawaii Medical Journal, 1981, 40, 9798.

Kutz S.J., Hoberg E.P., Nishi J. \& POlley L. Development of the muskox lunworm, Umingmakstrongylus pallikuukensis (protostrongylidae), in gastropods in the Arectic. Canadian Journal of Zoology, 2002, 80, 1977-1985

LOKER E.S. A comparative study of the life-histories of mammalian schistosomes. Parasitology, 1983, 87, 343-369.

Lwambo N.J., Upatham E.S., Kruatrachue M. \& Viyanant V. The host-parasite relationship between the Saudi Arabian Schistosoma mansoni and its intermediate and definitive hosts. 1. S. mansoni and its local snail host Biomphalaria arabica. Southeast Asian Journal of Tropical Medicine E Public Health, 1987, 18 (2), 156-165.

MackerRas M.J. \& SANDARS D.F. Life history of the rat lungworm and its migration through the brain of its hosts. Nature, 1954, 173, 956-958.

MACKERRAS M.J. \& SANDARS D.F. The life history of the rat lungworm, Angiostrongylus cantonensis (Chen) (Nematoda: Metastrongylidae). Australian Journale of Zoology, 1955, 3, 1-25.

Minchella D.J., Leathers, B.K., Brown K.M. \& McNair J.N. Host and parasite counteradaptations: An example from a freshwater snail. The American Naturalist, 1985, 126, 843854.

NiEMANN G.M. \& LEWIS F.A. Schistosoma mansoni: influence of Biomphalaria glabrata size on susceptibility to infection and resultant cercarial production. Expermental Parasitology, 1990, 70 (3), 286-292.

Poulin R. The disparity between observed and uniform distributions: a new look at parasite aggregation. International Journal of Parasitology, 1993, 23, 937-944.

ROLLINSON D., STOTHARD J.R. \& SOUTHGATE V.R. Interactions between intermediate snail hosts of the genus Bulinus and schistosomes of the Schistosoma haematobium group. Parasitology, 2001, 123, S245-S260.

Rosen L., Loison G., Laigret J. \& Wallace G.D. Studies on eosinophilic meningitis. 3. Epidemiologic and clinical observations on Pacific islands and the possible etiologic role of Angiostrongylus cantonensis. American Journal of Epidemiology, 1967, 85, 17-44. 
Rubio-Godoy M. \& Tinsley R.C. Comparative susceptibility of brown trout and rainbow trout to Discocotyle sagittata (Monogenea). Journal of Parasitolology, 2004, 90 (4), 900901.

Slom T. \& Johnson S. Eosinophilic Meningitis. Current Infectious Disease Reports, 2003, 5, 322-328.

Southgate V.R. Schistosomiasis in the Senegal River Basin: before and after the construction of dams at Diama, Senegal and Manantali, Mali and future prospects. Journal of Helminthology, 1997, 71, 125-132.

Uchikawa R., Takagi M., Matayoshi S. \& Sato A. The presence of Angiostrongylus cantonensis in Vitu Levu, Fiji. Journal of Helminthology, 1984, 58, 231-234.

WHO. Snail control, the prevention of Bilharziasis. Monograph, 1965, series No. 50, Geneva.

Woolhouse M.E. On the interpretation of age-prevalence curves for schistosome infections of host snails. Parasito$\log y, 1989,85$, 454-463.

YousIF F. \& LÄMmLER G. The suitability of several aquatic snails as intermediate hosts for Angiostrongylus cantonensis. Z. Parasitenkd., 1975, 47 (3), 203-210.

Yousif F. \& Ibrahim A. The first record of Angiostrongylus cantonensis from Egypt. Z. Parasitenkd., 1978, 56 (1), 7380.

Yousif F., Roushdy M. \& El-Emam M. The host-parasite relationships of Angiostrongylus cantonensis in Egypt. Journal of Egyptian Society of Parasitology, 1989, 10 (2), 399-412.

Reçu le 16 mars 2006 Accepté le 30 octobre 2006 